\begin{tabular}{ccc}
\hline International Journal of Engineering \& Technology, $7(2.8)(2018) 588-591$ \\
SPC & Website: www.sciencepubco.com/index.php/IJET \\
Research Paper & International Journal of Engineering \& Technology \\
\hline
\end{tabular}

\title{
Design and fabrication of an economical coconut Dehusking machine
}

\author{
Krishnan.R ${ }^{1 *}$, Mahalingam.P.P', Samuel Ratna kumar.P.S ${ }^{3}$, Babu. $\mathbf{T}^{4}$ \\ Department of Mechanical Engineering, \\ ${ }^{1,2}$ Karpagam College of Engineering, Coimbatore, Tamilnadu, India \\ ${ }^{3}$ Kumaraguru College of Technology, Coimbatore, Tamilnadu, India \\ ${ }^{4}$ Sri Sairam Engineering College, Chennai, Tamilnadu, India \\ *Corresponding Author E-mail: krishnan2992@gmail.com
}

\begin{abstract}
A coconut is the fruit of a coconut palm belonging to arecaceae family and it is used by one third of the population in the world. The coconut needs to be dehusked before it could be utilized for any of the purpose it serves. The husk of the coconut can be removed by various techniques. Manual dehusking is the conventional process followed widely among farmers. The labour cost incurred and the time consumed can be considerably decreased by increasing the usage of machines. All the coconut growers cannot afford to own an automated machines used in developed countries because of high cost. This project attempts in making a dehusker which is affordable and also has higher productivity. The cost of the dehusking machine is also affordable which makes it better than hydraulic dehusking machine. The machine has two rotating shafts with spikes mounted on a frame. The shafts are rotated by a three phase motor. The output speed is reduced to $30 \mathrm{rpm}$ by using gear box. When the coconut is placed between the spiked shafts rotating in opposite directions, the husk is peeled off from the coconut
\end{abstract}

Keywords: Dehusking, Machine, Affordable, Productivity

\section{Introduction}

A coconut is the fruit of a coconut palm belonging to arecaceae family. It consists of a hard shell covering the edible portion. A fibrous outer layer known as the husk, covers the shell. Hence the coconut has to be dehusked before it can be used for any purpose. The size of a coconut with husk varies from 145 to $200 \mathrm{~mm}$ in diameter and it can be 200 to $300 \mathrm{~mm}$ long [1-3]. The manual dehusking process is time consuming and it also involves the risk of the labourer getting injury. Labour fatigue also contributes to the low productivity. The labour cost for dehusking a coconut is 50 paise/coconut. At the end of the day the cost for dehusking one load coconut (1000 nuts) is Rs.500. Expensive hydraulic dehusking machines are capable of dehusking 300 nuts / hour and requires skilled labours. The Dehusking machines available in the market are costly. And that restricts the adoption of this technique among small scale farmers. Hence the machines should be made available at an affordable price to increase their usage [4-5]. The present work involves designing, fabricating and analysing a coconut dehusking machine which overcomes the cost barrier and makes the machine available at low cost. Controllers design for non-linear systems has been reported [10-19].

\section{Proposed Design}

The proposed dehusking machine is driven my motor and it peels the husk from the dry coconut with the help of systematically arranged spikes on shafts. The dry coconuts are placed in between the two shafts. The shafts have spikes welded on them and rotate in opposite directions. The rolling motion of the roller shafts allows the spikes to penetrate the husk and peel them off the nuts. The proposed design consists of a power source to drive the shafts, a gear box to reduce the speed, chain and gear drive to transmit power, bearings and a frame to mount and support all the components. A 3 phase induction 740 watts motor is used to drive the mechanism. The drive from the motor is transmitted to the gear box for speed reduction. The speed of rotation of the output shaft of the motor is 1440rpm. The motor output shaft is connected directly to the gear box using a love jaw coupling which completely reduces the transmission losses. The gear box and the motor is mounted on the lower part of the frame. Care was taken that the motor shaft and the gear box input shaft were in straight line to minimize the vibration and completely utilize the power of the motor.

\section{Motor Requirement Calculation}

- 3 phase induction motor with 1440rpm

- $\quad$ Shaft radius $=25 \mathrm{~mm}$

- $\quad$ Tearing force required $=20 \mathrm{kgf}$

- Power required in tearing: [ $(20 * 9.81)(2 * 3.14 * .025)$ $(100 / 60)] * 4=210 \mathrm{w}$

- Power required for driving the coconut: [ $(20 * 9.81)(3 / 60)$ ] $=10 \mathrm{w}$

- $\quad$ Total power required $=210+10=220 \mathrm{w}$

The gear box used in this machine has a speed ratio of 48:1. This reduces the speed from $1440 \mathrm{rpm}$ to $30 \mathrm{rpm}$. The worm gear mechanism is used in the designed gear box for reducing the output speed. Reducing the output speed, increases the torque produced from the motor. 


\section{Gearbox Specification}

- $\quad$ Speed ratio is 48:1.

- $\quad$ Speed Reduction: 960rpm to 30rpm.

- $\quad$ Diameter of output shaft $=25 \mathrm{~mm}$

Belts and ropes drive could slip and strain hence there are not preferred. Chain and gear drives are preferably used for small distance power transmission [6]. The power from the chain is transmitted to the shaft by means of sprocket.

- $\quad$ No of teeth in the sprocket attached to the gear box $=18$

- No of teeth in the chain pulley attached to the spur gear=40

- Total length of the chain $=2400 \mathrm{~mm}$

Two $30 \mathrm{~mm}$ shafts are stepped into $20 \mathrm{~mm}$ at the both ends of the shaft. This stepped end is connected to the bearings that are supported by the frame. The bearing to be used should provide proper balancing of shafts. The 6200 series maintenance free, selflubricating bearing suits the requirement well.

\section{Bearing Specification}

- $\quad$ Bearing series $=6200$ series

- $\quad$ Bearing Number $=6202$

- Diameter of the bearing $=20 \mathrm{~mm}$

\section{Shaft Specification}

- $\quad$ Shaft-Mild steel

- Length of the shaft $=750 \mathrm{~mm}$.

- Number of shaft $=2$

- $\quad$ Diameter of the shaft $=30 \mathrm{~mm}$

- $\quad$ Stepped diameter at the both ends of the shaft $=20 \mathrm{~mm}$

- $\quad$ Stepped length at the both ends of the shaft $=100 \mathrm{~mm}$

A Spur gear is attached to the other stepped end of each shaft and they mesh with another to rotate the shafts in opposite direction.

\section{Gear Specification}

- Gear type - Spur gear

- Number of teeth in the driver gear $=40$

- No of teeth in the driven gear=40

- Diameter of the gear $=60 \mathrm{~mm}$

- Centre distance between gears $=120 \mathrm{~mm}$

Spikes are made from the shaft of $10 \mathrm{~mm}$ diameter. They are cut into smaller pieces. Sharp edge is been formed and then the spike has been welded on to the rotating shaft [7]. It is necessary that the material used has more hardness. The design of the spike is shown in figure 1 . The spikes are sharpened and spaced from one another substantially equal distance where by the patterned array in which the plurality of spikes are positioned which facilitates the penetration through the husk and peel them off.

\section{Spike Specification}

- $\quad$ Total length of the spike $=30 \mathrm{~mm}$

- Sharpened length of the spike at the end of the rod $=5 \mathrm{~mm}$

- $\quad$ Angle of the sharpened edge $=135$ degree

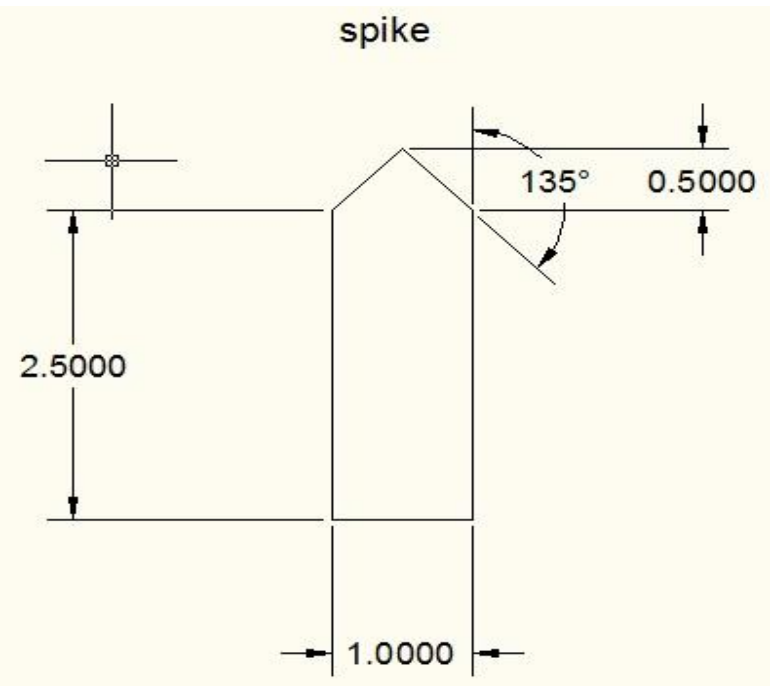

Fig. 1: Design of the spikes
The Design of the proposed machine is shown in figure $2-5$.

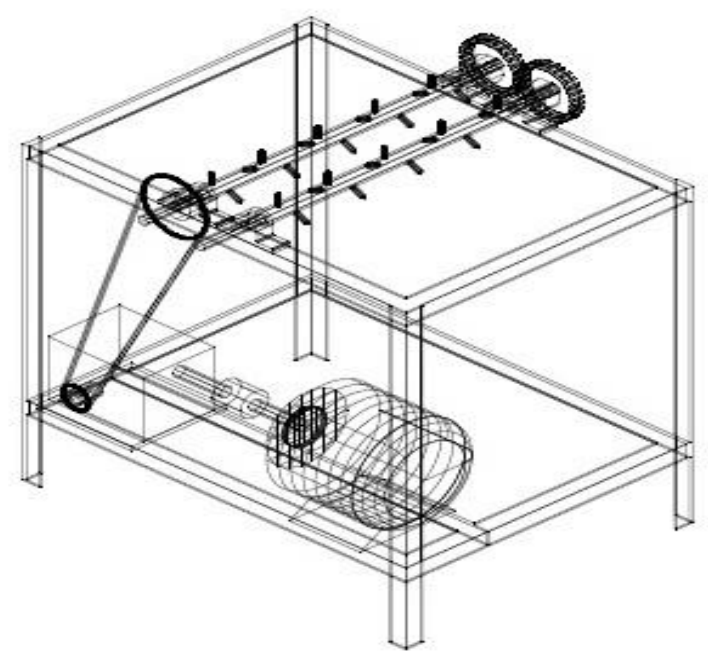

Fig. 2: 3D view of the Dehusker

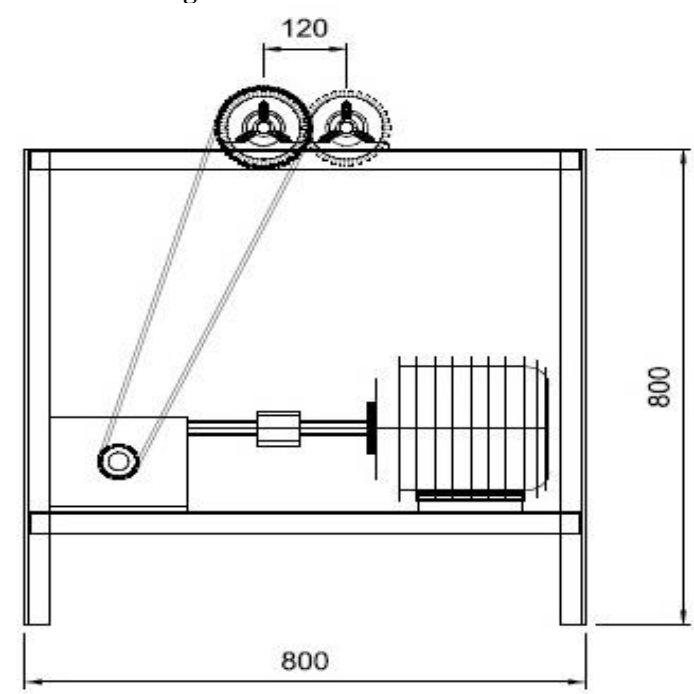

Fig. 3: Front view of the Dehusker

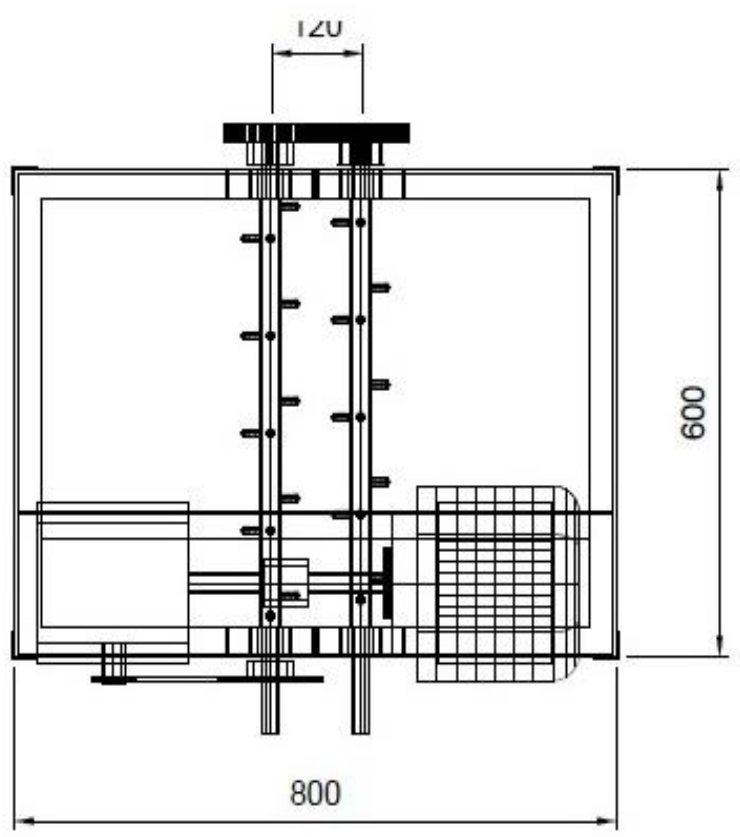

Fig. 4: Top view of the Dehusker 


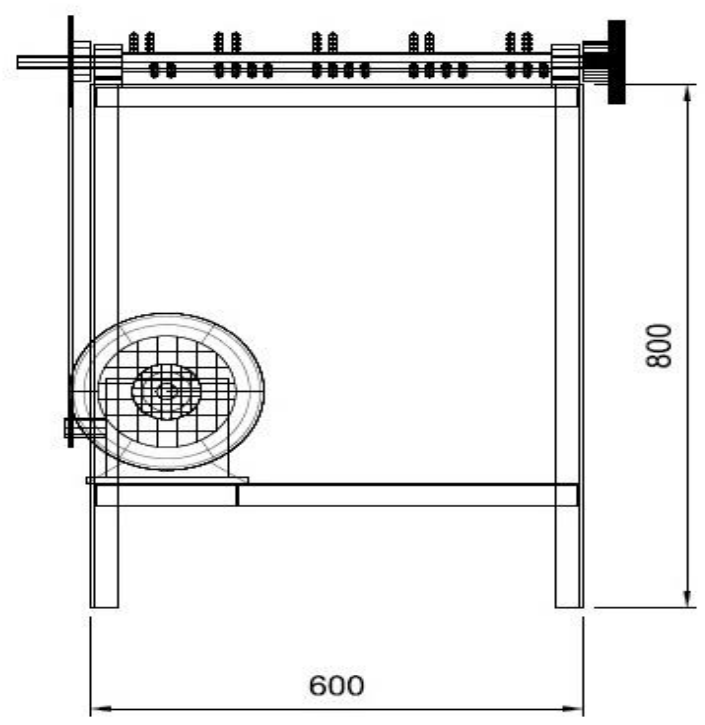

Fig. 5: Side view of the Dehusker

The various materials used for different components in the proposed coconut dehusker are listed below in the table 1 .

Table 1: Components of the Dehusker

\begin{tabular}{|l|l|l|l|}
\hline SN & DESCRIPTION & MATERIAL & DIMENSIONS \\
\hline 1 & Frame (L angle) & Mild Steel & $35^{*} 35^{*} 4 \mathrm{~mm}$ \\
\hline 2 & Gear Box & Speed Reduction & O/P 30 rpm \\
\hline 3 & Motor & $3 \phi$ Motor & O/P 960 rpm \\
\hline 4 & Bearing & Mild Steel & $\phi 20^{*} 6202$ Series \\
\hline 5 & Spur Gear & Mild Steel & $\phi 27 * 20 \mathrm{~mm} 40 \mathrm{t}$ \\
\hline 6 & Chain & Mild Steel & $2500 \mathrm{~mm}$ \\
\hline 7 & Sprocket & Mild Steel & $\phi 160 * 6 \mathrm{~mm} \mathrm{40t}$ \\
\hline 8 & $\begin{array}{l}\text { Sprocket Gear } \\
\text { box })\end{array}$ & Mild Steel & $\phi 65^{*} 10 \mathrm{~mm} 18 \mathrm{t}$ \\
\hline 9 & Spike & Mild Steel & $\phi 10^{*} 30 \mathrm{~mm}$ \\
\hline 10 & Shaft & Mild Steel & $\phi 30^{*} 700 \mathrm{~mm}$ \\
\hline 11 & Bolts \& Nuts & Mild Steel & M12*26mm \\
\hline 12 & Bolts \& Nuts & Mild Steel & M10*50mm \\
\hline
\end{tabular}

\section{Fabrication of the System}

Frame was constructed by welding the $\mathrm{L}$ angles. The frame has a base to hold the motor and gear box. The positions of the motor and gear box are fixed and fastened using bolts and nuts to the frame. The positions of the shafts are fixed on the top of the frame and fastened using bolts and nuts. The spikes are welded around the shaft in multiple positions in such a way to peel the husk. The sharpened spikes are spaced at a substantial equal distance. The patterned array positions of the spikes are positioned to grip the coconut and penetrate the husk and tear them off. High torque is attained by rotating the shafts at lower rpm. The spikes provide a tearing action on the husk, once penetrated into the outer layer of the coconut. The motor and the gear box are coupled together using a love jaw coupling. The reduced speed drive is transmitted to the shafts from the gear box using chain and sprocket. The shafts are interlinked using a pair of spur gear mounted on the stepped end of the shafts. The Gears are meshed to rotate in opposite direction. Now the drive is connected and the coconut is placed between the shafts for dehusking.

\section{Working and Cost Analysis}

While the traditional spike iron method can give a productivity of 50 nuts per hour [8], the fabricated machine can dehusk around 70 nuts per hour. It can be operated by unskilled labours and the risk of injury to the labours is eliminated. The cost incurred in fabricating this dehusking machine is given in table 2 .

Table 2: Cost of Fabrication

\begin{tabular}{|l|l|l|l|}
\hline S.NO & DESCRIPTION & QUANTITY & COST \\
\hline 1 & L Angle Plates & $18 \mathrm{~m}$ & 1500.00 \\
\hline 2 & Gear Box & 1 & 3500.00 \\
\hline 3 & $3 \phi$ Motor & 1 & 3500.00 \\
\hline 4 & Bearing & 4 & 660.00 \\
\hline 5 & Spur Gear & 2 & 1600.00 \\
\hline 6 & Chain Sprocket Set & 1 & 950.00 \\
\hline 7 & $\begin{array}{l}\text { Mild Steel Rod } \\
(\phi 30 \mathrm{~mm})\end{array}$ & 2 & 1100.00 \\
\hline 8 & $\begin{array}{l}\text { Mild Steel Rod } \\
(\phi 10 \mathrm{~mm})\end{array}$ & $1200 \mathrm{~mm}$ & 850.00 \\
\hline 9 & $\begin{array}{l}\text { Bolts \& Nuts } \\
(\text { M10*50mm) }\end{array}$ & 8 & 70.00 \\
\hline 10 & $\begin{array}{l}\text { Bolts \& Nuts } \\
(\text { M12*26mm) }\end{array}$ & 8 & 85.00 \\
\hline 11 & Machining Charges & - & 2000.00 \\
\hline & \multicolumn{2}{|l}{} \\
\hline
\end{tabular}

\section{Conclusion}

Dehusking machine has been implemented in the field of agriculture to increase the productivity and reduce the requirement of skilled man power. The cost has been a barrier for small scale farmer in adapting to this technology [9]. A Simple mechanism to dehusk the coconut has been implemented in this machine to overcome the high cost barrier and make it affordable for small scale farmers. Coconut dehusker is available at an affordable cost and can be utilized up to its potential. The machine provides a good productivity with less human interaction. It does not need skilled labour and ha low maintenance. It can be easily dismantled and carried from one place to another with ease. The future scope of this work is to overcome the limitation of coconut size that could be dehusked and to automate the process of loading and unloading of the coconut.

\section{References}

[1] Sabale.R.M and K.P.Kohle, 'Design and Development of a Coconut Dehusker for Small Scale Coir Industry and Marginal Farmers', International Journal of Science, Engineering and Technology Research, 5(2), 2016.

[2] Piyathissa.S.D.S and Kahandage.P.D, 'Introducing an appropriate mechanical way for Coconut dehusking', Procedia Food Science, 6, pp. 225 - 229, 2015.

[3] Nijaguna.B.T, 'Coconut dehusker', Journal of Food Engineering, 8(4), pp. 287-301, 1988

[4] G. Sujaykumar, Shashidhar B. Asantapur, Vishwas C., Prashanth Kumar, Dhanush D., 'Design and Fabrication of Coconut Dehusker', Journal of Mechanical Engineering and Automation, 7(3), pp. 77-81, 2017.

[5] Roopashree C R, 'Design and Development of Coconut Dehusking Machine', International Journal of Engineering Development and Research, 5(3), 2017.

[6] P.A.Wadile1, K.P.Kolhe, 'Design and Development of Coconut Dehusking Machine: A Review', International Journal of Advance Engineering and Research Development, 4(5), 2015.

[7] Abishek D, Aravind S, Arun Koushik, Karthick M and Priyadharsini S, 'Design and Fabrication of Automatic Coconut Dehusking Machine', International Journal of Innovative and Emerging Research in Engineering, 4(1) 2017.

[8] Dany Thomas, Ajmal K and Deepak Devassia, 'Design and Fabrication of low cost coconut Dehusking machine', International Journal of Engineering Research and General Science, 5(3), 2017.

[9] Nwankwojike BN, Onuba O and Ogbonna U. 'Development of a Coconut Dehusking Machine for Rural Small Scale Farm Holders', International Journal of Innovative Technology \& Creative Engineering, 3(2), pp1-7, 2012. 
[10] R. Kalaivani, K. Ramash Kumar, S. Jeevananthan, "Implementation of VSBSMC plus PDIC for Fundamental Positive Output Super Lift-Luo Converter," Journal of Electrical Engineering, Vol. 16, Edition: 4, 2016, pp. 243-258.

[11] K. Ramash Kumar,'Implementation of Sliding Mode Controller plus Proportional Integral Controller for Negative Output Elementary Boost Converter," Alexandria Engineering Journal (Elsevier), 2016, Vol. 55, No. 2, pp. 1429-1445.

[12] P. Sivakumar, V. Rajasekaran, K. Ramash Kumar, "Investigation of Intelligent Controllers for Varibale Speeed PFC Buck-Boost Rectifier Fed BLDC Motor Drive," Journal of Electrical Engineering (Romania), Vol.17, No.4, 2017, pp. 459-471.

[13] K. Ramash Kumar, D.Kalyankumar, DR.V.Kirbakaran" An Hybrid Multi level Inverter Based DSTATCOM Control, Majlesi Journal of Electrical Engineering, Vol. 5. No. 2, pp. 17-22, June 2011, ISSN: 0000-0388.

[14] K. Ramash Kumar, S. Jeevananthan, “A Sliding Mode Control for Positive Output Elementary Luo Converter," Journal of Electrical Engineering, Volume 10/4, December 2010, pp. 115 127.

[15] K. Ramash Kumar, Dr.S. Jeevananthan,” Design of a Hybrid Posicast Control for a DC-DC Boost Converter Operated in Continuous Conduction Mode" (IEEE-conference PROCEEDINGS OF ICETECT 2011), pp-240-248, 978-1-42447925-2/11.

[16] K. Ramash Kumar, Dr. S. Jeevananthan,” Design of Sliding Mode Control for Negative Output Elementary Super Lift Luo Converter Operated in Continuous Conduction Mode", (IEEE conference Proceeding of ICCCCT-2010), pp. 138-148, 978-14244-7768-5/10.

[17] K. Ramash Kumar, S. Jeevananthan, S. Ramamurthy" Improved Performance of the Positive Output Elementary Split InductorType Boost Converter using Sliding Mode Controller plus Fuzzy Logic Controller, WSEAS TRANSACTIONS on SYSTEMS and CONTROL, Volume 9, 2014, pp. 215-228.

[18] N. Arunkumar, T.S. Sivakumaran, K. Ramash Kumar, S. Saranya, "Reduced Order Linear Quadratic Regulator plus Proportional Double Integral Based Controller for a Positive Output Elementary Super Lift Luo-Converter," JOURNAL OF THEORETICAL AND APPLIED INFORMATION TECHNOLOGY, July 2014. Vol. 65 No.3, pp. 890-901.

[19] Arunkumar, T.S. Sivakumaran, K. Ramash Kumar, "Improved Performance of Linear Quadratic Regulator plus Fuzzy Logic Controller for Positive Output Super Lift Luo-Converter," Journal of Electrical Engineering, Vol. 16, Edition: 3, 2016, pp 397-408.

[20] T. Padmapriya and V. Saminadan, "Inter-cell Load Balancing Technique for Multi- class Traffic in MIMO - LTE - A Networks", International Conference on Advanced Computer Science and Information Technology, Singapore, vol.3, no.8, July 2015.

[21] S.V.Manikanthan and V.Rama "Optimal Performance of Key Predistribution Protocol In Wireless Sensor Networks" International Innovative Research Journal of Engineering and Technology, ISSN NO: 2456-1983, Vol-2, Issue -Special March 2017. 